\title{
Prolonged dystonic reaction to chlorpromazine in myxoedema coma
}

\author{
G. M. WoOD \\ B.Sc., M.B. B.S.
}

\author{
A. K. WATERS \\ M.A., M.B., B.Chir., M.R.C.P.
}

Wharfedale General Hospital, Otley, West Yorkshire

\begin{abstract}
Summary
A case of myxoedema coma is reported where the administration of chlorpromazine resulted in a prolonged dystonic reaction. A similar challenge with a butyrophenone when the patient was on thyroxine caused a similar but much abbreviated response.

\section{Introduction}

Hypothyroidism is associated with a decreased rate of metabolism of a number of commonly used drugs (Evered, 1976). Side effects of such drugs, therefore, may be prolonged. Dyskinetic reactions can result from the administration of phenothiazines and the authors report here a prolonged dystonic reaction to a single dose of chlorpromazine in a patient with myxoedema coma.
\end{abstract}

\section{Case report}

A 75-year-old woman was admitted to another hospital because of self-neglect. She was known to be hypothyroid and supposedly taking $0.2 \mathrm{mg}$ L-thyroxine daily but her general practitioner had found a large quantity of these tablets in her house.

On the first evening she received $50 \mathrm{mg}$ of chlorpromazine i.m. for sedation. The following evening she was transferred to Wharfedale General Hospital where, on admission, she was hypothermic (rectal temperature $33^{\circ} \mathrm{C}$ ), confused and unresponsive with delayed tendon reflexes.

Muscle spasms of all 4 limbs, neck retraction and myoclonic twitches of the facial muscles suggested an acute dystonic reaction. Thyroid function tests at that time showed: serum total thyroxine $50 \mathrm{nmol} / 1$ (normal range 62-166); triiodothyronine resin uptake $\left(T_{3}\right.$ resin) $127 \%$ (normal range, 177-92); free thyroxine index 3.6 (normal range, $3 \cdot 5-12 \cdot 5$ ); serum thyroid stimulating hormone (TSH), $110 \mu \mathrm{u} . / \mathrm{ml}$ (normal range, up to 7). Lumbar puncture revealed: red cells $<$ one $/ \mathrm{mm}^{3}$; white cells $<$ one $/ \mathrm{mm}^{3}$; no organisms on microscopy or culture; protein 0.33 $\mathrm{gm} / \mathrm{l}$; glucose $3.6 \mathrm{mmol} / \mathrm{l}$.

She was treated with triiodothyronine $10 \mu \mathrm{g}$ i.v. 8 hourly and hydrocortisone acetate $100 \mathrm{mg}$ i.v. 6 hourly. Two mg of benztropine were administered i.v. for the dystonia and repeated $3 \mathrm{hr}$ later with initial improvement of the dystonic signs on eact $\overrightarrow{\mathrm{t}}$ occasion. However, she was still showing dyskinetie movements the next morning, $40 \mathrm{hr}$ after the chlor promazine had been given. $A$ third injection $a \bar{B}$. benztropine ( $2 \mathrm{mg}$ i.v.) was administered and the dystonia had fully recovered after a further $8 \mathrm{hr}$.

Two weeks later she was clinically much improve® and re-established on oral L-thyroxine (serum totat thyroxine $61 \mathrm{nmol} / 1 ; \mathrm{T}_{3}$ resin, $117 \%$; free thyroxine index, $4 \cdot 1$; serum TSH $50 \mu \mathrm{u}$. $/ \mathrm{ml}$ ).

However, one night she became agressive and confused and was sedated with $5 \mathrm{mg}$ of haloperido i.m. For the next $15 \mathrm{hr}$ she again showed dystoni signs, this time of minor degree.

\section{Discussion}

Chlorpromazine is normally metabolized in 勇e liver and excreted in the urine and faeces. Although metabolites can be found in the urine 6 months after the last dose has been administered, the plasma half life of chlorpromazine is about $6 \mathrm{hr}$ (Goodman and Gilman, 1975). Dystonic reactions have been de scribed in association with phenothiazines and usually occur soon after the drug has been started (Richter, 1969). The syndrome is characterized by involuntary tongue movement, facial grimacing. oculogyric crises, retrocollis and opisthotonos. The signs disappear when the drug responsible is with:drawn (Davies, 1977). Benztropine can be used to. expedite recovery, beneficial effects becoming apparent $10 \mathrm{~min}$ after administration. Chlorpro mazine is not usually associated with such reactionso only 5 such cases being listed in the Committee on Safety of Medicines' Register of Adverse reactions? 1962-1977.

The patient showed typical features of an acute dystonic reaction but myoclonic twitching was stiln occurring $40 \mathrm{hr}$ after a single dose of chlorpromazine् and 3 doses of benztropine. Whilst others have reported the occasional need for a second dose of benztropine or similar drug the present authors car find no record of a dystonic reaction lasting this length of time (Dundee, Clark and Carruthers; 1975).

It is presumed that the prolonged response was du串 
to the decreased rate of metabolism which occurs with hypothyroidism and hypothermia and that the second episode was shorter because of the patient's improved thyroid status. This report adds further evidence that great caution should be used in prescribing drugs for patients suffering from hypothyroidism as adverse drug reactions may be prolonged.

\section{Acknowledgments}

We thank Dr G. Wallis (consultant psychiatrist) for permission to report this case.

\section{References}

Davies, D.M. (1977) Textbook of Adverse Drug Reactions, p. 306. Oxford University Press, Oxford.

Dundee, J.W., Clark, R.S.S. \& Carruthers, S.G. (1975) Drug-induced extrapyramidal disorders. Prescribers' Journal, 15, 26.

Evered, D.C. (1976) Diseases of the Thyroid, p. 171. Pitman Medical, Tunbridge Wells.

Goodman, L.S. \& Gilman, A. (1975) The Pharmacological Basis of Therapeutics, 5th Edn, p. 163. MacMillan Publishing Co., New York.

RichTER, T. (1969) Akute Dyskinesien nach kurzfristiger antiemetischer Medikation. Schweizerische medizinische Wochenschrift, 99, 1107. 